\title{
The Atr and Atm protein kinases associate with different sites along meiotically pairing chromosomes
}

\author{
Kathleen S. Keegan, ${ }^{1,6}$ Douglas A. Holtzman, ${ }^{1,6,7}$ Annemieke W. Plug, ${ }^{2}$ Erik R. Christenson, ${ }^{1}$ \\ Elizabeth E. Brainerd, ${ }^{2}$ Gail Flaggs, ${ }^{1}$ Nicola J. Bentley, ${ }^{4}$ Elaine M. Taylor ${ }^{4}{ }^{4}$ M. Stephen Meyn, ${ }^{2,3}$ \\ Stuart B. Moss, ${ }^{5}$ Antony M. Carr, ${ }^{4}$ Terry Ashley, ${ }^{2}$ and Merl F. Hoekstra ${ }^{1,8}$ \\ ${ }^{1}$ ICOS Corporation, Bothell, Washington 98021 USA; $^{2}$ Departments of Genetics and ${ }^{3}$ Pediatrics, Yale University School of \\ Medicine, New Haven, Connecticut 06510 USA; ${ }^{4}$ MRC Cell Mutation Unit, Sussex University, Falmer, BNI 9RR, UK; \\ ${ }^{5}$ Department of Obstetrics and Gynecology, University of Pennsylvania School of Medicine, \\ Philadelphia, Pennsylvania 19104 USA
}

A number of cell-cycle checkpoint genes have been shown to play important roles in meiosis. We have characterized the human and mouse counterpart of the Schizosaccharomyces pombe Rad3 protein, named Atr (for ataxia-telangiectasia- and rad3-related), and the protein that is mutated in ataxia-telangiectasia, Atm. We demonstrate that $A T R$ mRNA and protein are expressed in human and mouse testis. More detailed analysis of specific cells in seminiferous tubules shows localization of Atr to the nuclei of cells in the process of meiosis I. Using immunoprecipitation and immunoblot analysis, we show that Atr and Atm proteins are $\sim 300$ and $350 \mathrm{kD}$ relative molecular mass, respectively, and further demonstrate that both proteins have associated protein kinase activity. Further, we demonstrate that Atr and Atm interact directly with meiotic chromosomes and show complementary localization patterns on synapsing chromosomes. Atr is found at sites along unpaired or asynapsed chromosomal axes, whereas Atm is found along synapsed chromosomal axes. This is the first demonstration of a nuclear association of Atr and Atm proteins with meiotic chromosomes and suggests a direct role for these proteins in recognizing and responding to DNA strand interruptions that occur during meiotic recombination.

[Key Words: Atr; Atm; protein kinase; meiosis]

Received July 29, 1996; revised version accepted August 23, 1996.

Mitotic cells guard against genetic instability and increase their survival following DNA damage both by direct DNA repair mechanisms and by delaying progression through the cell cycle. Depending on the position of the cell within the cell cycle at the time of irradiation, DNA damage in mammalian cells can effect specific checkpoints that prevent passage from $G_{1}$ to $S$ phase, progression through $S$ phase, or passage from $G_{2}$ into mitosis. These checkpoints are thought to prevent deleterious events such as replication of damaged DNA or the segregation of fragmented chromosomes during mitosis (Hartwell and Kastan 1994) and therefore assure the accurate transmission of the genetic material. Recently it has been shown that mitotic checkpoint proteins can have a role in meiosis (Kato and Ogawa 1994; Hari et al. 1995; Xu et al., this issue).

In mitotic cells, $G_{1}$ arrest following DNA damage is

\footnotetext{
${ }^{6}$ These authors contributed equally to this work.

${ }^{7}$ Present address: Millennium Pharmaceuticals Inc., Cambridge, Massachusetts 02139 USA.

${ }^{8}$ Corresponding author.
}

dependent on the product of the $p 53$ gene, which is stabilized following DNA damage (Nelson and Kastan 1994). p53 is a transcription factor that induces production of $\mathrm{p} 21^{\mathrm{CIP} 1 / W A F-1}$, a direct inhibitor of cyclin-dependent kinase activity (El-Deiry et al. 1993; Harper et al. 1993; Deng et al. 1995/. Loss of $G_{1}$ arrest is not associated directly with loss of viability following irradiation in mammalian cells, but appears to be linked to genomic instability, an early event in tumorigenesis (Hartwell and Kastan 1994). Treatment of replicating cells with ionizing radiation transiently prevents progression through $S$ phase by reducing the number of replication initiation events (Lamb et al. 1989). Cells from patients with ataxia-telangiectasia $(\mathrm{A}-\mathrm{T})$, an autosomal recessive disease that is characterized by progressive cerebellar degeneration, immune deficiencies, increased incidences of cancer, gonadal abnormalities, sterility, and sensitivity to ionizing radiation (Sedgwick and Boder 1991), have lost the delay in $\mathrm{S}$ phase following ionizing radiation and display radiation-resistant DNA synthesis (Painter and Young 1980). The pleiotropic A-T phenotype is thought to be due to an inability of multiple cellular functions to 
be activated in response to certain types of spontaneous and induced DNA damage (for review, see Meyn 1995; Shiloh 1995). For example, A-T cells irradiated in $G_{1}$ or $S$ phase accumulate irreversibly in $G_{2}$ where they subsequently die from apoptosis, presumably as a consequence of attempting to replicate damaged DNA or entering mitosis with unrepaired chromosomal damage (Meyn 1995; Shiloh 1995). A-T cells irradiated during $G_{2}$ fail to pause transiently prior to entering mitosis. Consequently they progress through mitosis with damaged DNA (Beamish and Lavin 1994). In addition, the induction of p53 in irradiated A-T cells is blunted and delayed (Kastan et al. 1992; Canman et al. 1994). Thus, mutations at the A-T locus result in the disruption of at least three checkpoints required for appropriate responses to ionizing radiation and radiomimetic mutagens.

Identification of $A T M$, the gene mutated in $\mathrm{A}-\mathrm{T}$, showed that the Atm protein is similar to a family of phosphatidylinositol 3-kinase (PIK)-like kinases (Savitsky et al. 1995). This family, which includes the products of the TOR1, TOR2, FRAP, TEL1, MEC1, rad3, mei-41, ATR genes, and the DNA-dependent protein kinase catalytic subunit (DNA-PK $\mathrm{Cs}_{\mathrm{C}}$ ), shows greatest similarity throughout the protein kinase domain (Heitman et al. 1991; Seaton et al. 1992; Cafferkey et al. 1993; Kunz et al. 1993; Helliwell et al. 1994; Kato and Ogawa 1994; Weinert et al. 1994; Greenwell et al. 1995; Hari et al. 1995; Hartley et al. 1995; Bentley et al. 1996). All of these proteins appear to act as early sensors for defects in various cell-cycle transitions or aberrations in chromosomal mechanisms (Carr 1996). The Saccharomyces cerevisiae rapamycin-binding proteins, Tor $1 \mathrm{p}$ and Tor2p, and their mammalian counterparts, Frap and Raftl, play an important role in mediating the $G_{1}$ to $S$ transition (Heitman et al. 1991; Cafferkey et al. 1993; Kunz et al. 1993; Brown et al. 1994; Sabatini et al. 1994). Frap, which autophosphorylates on serine, plays a role in downstream signaling to $\mathrm{p} 70^{\mathrm{s} 6}$ kinase and cyclin-dependent kinases (Brown et al. 1994).

The product of the TEL1 gene, which is most highly related to Atm in primary structure $156 \%$ identity through the kinase and carboxy-terminal domains $\mid$, is required for proper telomere maintenance in $S$. cerevisiae (Greenwell et al. 1995) and plays a partially redundant role with the $M E C 1$ gene product in conferring resistance to DNA damage (Morrow et al. 1995). DNA-PK is required for $V(D) J$ recombination and for doublestranded break repair after ionizing radiation (Jackson and Jeggo 1995). Mice lacking DNA-PK have severe combined immunodeficiency (SCID; Blunt et al. 1995), and a similar equine syndrome is also the result of a DNA-PK deficiency (Wiler et al. 1995). Meclp from S. cerevisiae, Rad3 from $S$. pombe, and mei-41 from Drosophila melanogaster appear to be structural and functional homologs that play important roles in mitotic and meiotic cell-cycle checkpoints and DNA repair. The most closely related mammalian protein to these model system checkpoint proteins is Atr. Unlike Frap and DNAPK, biochemical activity for Atr and Atm previously has been unidentified.
The Rad3, Meclp, and Mei-41 group mediate several checkpoint responses in mitotic cells and are important for meiosis. Rad3 is involved in $S$ phase and $G_{2}-M$ cellcycle arrest following DNA damage. rad3 mutants fail to arrest in $G_{2}$ after $U V$ or ionizing irradiation and continue into mitosis even if DNA synthesis is incomplete (AlKhodairy and Carr 1992; Jimenez et al. 1992; Rowley et al. 1992). Rad3 possesses an associated protein kinase activity, and site-directed mutations in the protein $\mathrm{ki}$ nase domain that render the kinase inactive do not complement rad3 mutant defects, indicating that Rad3 protein kinase activity is required for checkpoint function (Bentley et al. 1996). Similarly, MEC1 is required for checkpoints at $\mathrm{G}_{2}-\mathrm{M}$ (Weinert et al. 1994) and S-phase transitions (Paulowich and Hartwell 1995) and is essential for meiosis (Kato and Ogawa 1994). Finally, mei-41 mutant flies are highly sensitive to DNA damaging agents such as ionizing radiation, UV radiation, chemical mutagens, and hydroxyurea (Baker et al. 1976; Boyd et al. 1976; Banga et al. 1986), and cells from these mutants have defects in mitotic checkpoints (Hari et al. 1995 ) and in meiotic recombination (Baker and Carpenter 1972).

The human counterpart of Rad3, Meclp, and Mei-41, named Atr (for ataxia telangiectasia and rad3-related), has been identified (Bentley et al. 1996; Cimprich et al. 1996). Through the conserved kinase and carboxyl terminus, Atr is $53 \%$ identical to Schizosaccharomyces pombe $\operatorname{Rad} 3,48 \%$ identical to Mei-41, $41 \%$ identical to Meclp, $31 \%$ identical to Atm, and $32 \%$ identical to Tellp (Bentley et al. 1996). The sequence of ATR is identical to FRP1, a clone isolated previously from a Jurkat cDNA library (Cimprich et al. 1996). In S. pombe, Rad3 is in a homomultimeric complex (Bentley et al. 1996). Evidence that supports the notion that Atr is a functional Rad3 homolog has been suggested from the observation that Atr can heteromultimerize with $\operatorname{Rad} 3$ in vivo and that Atr can complement for mecl/esrl UV sensitivity (Bentley et al. 1996).

Signal transduction cascades, initiated by DNA damage or aberrant DNA replication, are thought to mediate the checkpoint responses (for review, see Carr 1996). Checkpoint pathways require three distinct functions: a detector molecule that recognizes abnormal DNA structures, a signaling cascade that amplifies and transmits the information, and effectors that interact with the cellcycle machinery (Carr 1996). Several candidate proteins for stages of this cascade have been identified, and most of these have mutant sensitivities to DNA-damaging agents. The Atm protein and the $\mathrm{Rad} 3 / \mathrm{Mec} 1 \mathrm{p} / \mathrm{Mei}-41 /$ Atr proteins are likely candidates as detectors of DNA damage or abnormal DNA replication in both mitotic and meiotic cells. Signal amplification could occur through the $\mathrm{Rad} 53 \mathrm{p} / \mathrm{Cds} 1$ protein kinase (Allen et al. 1994; Sanchez et al. 1996) and effectors might include proteins like p53 for $\mathrm{G}_{1}-\mathrm{S}$ transition; replication protein A (RPA) for S phase (Liu and Weaver 1993); and Chkl/ Rad27 for G2-M (Walworth et al. 1993; Al-Khodairy et al. 1994; Walworth and Bernards 1996).

In addition to playing a role in sensing DNA damage or 
completion of DNA synthesis in mitotic cells, MEC1 and mei-41 play important roles in meiosis (Baker and Carpenter 1972; Carpenter 1979; Kato and Ogawa 1994). Meiosis segregates a complete haploid set of chromosomes to each gamete, and this process requires the negotiation of a complex series of dependent events. Homologous chromosomes must associate, recombine, synapse, and segregate to opposite poles at meiosis I. DNA double-stranded breaks (DSBs) have been linked to the initiation of meiotic chromosomal synapsis in yeast (Petes et al. 1991). However, the events are much less clear in multicellular organisms. Both mec1 and mei-41 mutants are defective in meiotic processes (Baker and Carpenter 1972; Kato and Ogawa 1994). Likewise, the gonads of A-T patients and ATM-deficient mice have a paucity of germ cells (Sedgwick and Boder 1991; Barlow et al. 1996; Xu et al., this issue), and spermatocytes from $A T M^{-1-}$ mice show meiotic arrest in early prophase with severe chromosome fragmentation in aberrant pachytene nuclei (Xu et al., this issue). These observations suggest a link between functions carried out by mitotic checkpoint proteins and functions required for meiosis.

Here we report studies of Atr and Atm. We demonstrate that $A T R$ mRNA and protein are expressed at high levels in mouse testes. Our further studies show that Atr is localized to the nuclei of primary spermatocytes, cells that are undergoing meiosis I. We demonstrate that both Atr and Atm proteins have associated protein kinase activity, consistent with their primary structures. In addition, Atr and Atm show specific association with chromosomes in cells that are in early meiosis I as demonstrated by antibody localization on surface-spread spermatocytes. Both the Atr and Atm proteins are present at pairing forks in meiotic prophase as chromosomes synapse; however, they do not colocalize. Instead, they occupy complementary positions: Atr localizes along unsynapsed chromosome axes and Atm interacts with synapsed axes. This is the first demonstration that these cell-cycle checkpoint protein homologs specifically associate with chromosomal DNA and suggests a role for these Atm-like proteins in recognition of meiotic DNA configurations associated with meiotic synapsis.

\section{Results}

\section{Expression of ATR mRNA is elevated in testis}

In order to understand the role of Atr, the expression pattern was established by Northern blot analysis. All human tissues screened expressed a major transcript of $\sim 8.5 \mathrm{~kb}$. Expression levels were highest in testis with lower, but detectable levels, in all other tissues examined (Fig. 1A). As reported previously (Cimprich et al. 1996), ATR also shows low-level expression in a variety of cell lines (data not shown). An identical pattern of expression was seen upon probing of a multiple-tissue Northern blot containing mouse tissues with a mouse cDNA probe that showed $95 \%$ homology (Fig. 1B). These results demonstrated that the $A T R$ mRNA was elevated in testis, and this elevated expression pattern was conserved in mouse and man.

\section{Cell type-specific expression of Atr in testis}

To examine the protein product of Atr in greater detail, we generated Atr-specific antibodies. Antibodies directed toward the protein kinase domain or the carboxyl terminus recognized a protein in G361 and 293T cells (human melanoma and embryonic kidney cell lines, respectively) that migrated at an approximate molecular weight of $250-300 \mathrm{kD}$ (data not shown), consistent with the predicted molecular mass of Atr. Both antibodies recognize the same high molecular mass protein on immunoblots and immunoprecipitations, and reactivity with this protein was blocked by preincubation of the antibodies with the antigen against which it was directed (data not shown).

Since mouse testes were more readily obtained than human testes and the protein kinase domain of human and mouse Atr are identical (data not shown), the antisera were tested for cross reactivity on an adult mouse testes cell extract. Both antisera recognized a protein of the expected molecular weight (Fig. 2). These results confirm that the Atr protein was expressed in mouse testis.

To determine whether Atr expression in mouse testis was the result of nonspecific induction or reflected ex-

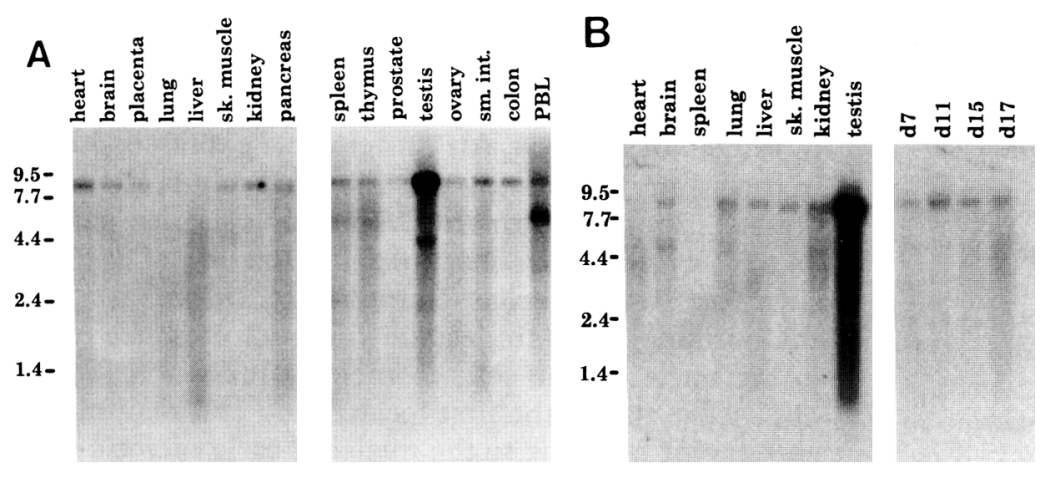

Figure 1. ATR mRNA is elevated in human and mouse testis. $(A)$ Northern blot containing poly $|\mathrm{A}|^{+}$RNA from various human tissues probed with a human $A T R$ probe. $(B)$ Northern blot containing poly $(\mathrm{A})^{+}$RNA from various mouse tissues and mRNA from total embryo at certain times in development probed with a mouse $A T R$ probe. $(\mathrm{d} 7)$ Day $7 ;(\mathrm{d} 11)$ day $11 ;(\mathrm{d} 15)$ day 15 ; (d17) Day 17. A 5-kb band is the result of incomplete removal of an unrelated probe from previous use of the Northern blot. The lower bands are likely to represent degradation products of $A T R$ mRNA because they vary depending on the lot of Northern blot. Approximate molecular weight standards in $\mathrm{kb}$ are shown at the left. 


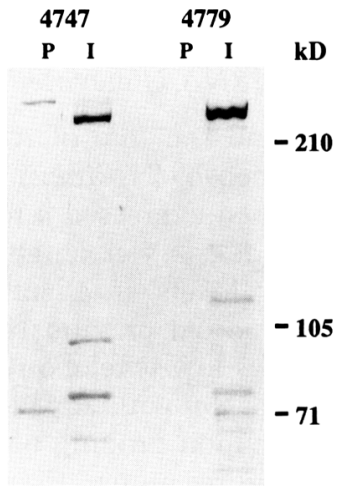

Figure 2. Atr protein is present in mouse testis. Two different rabbit antisera generated against Atr recognize the same protein in mouse testis. Immunoblot analysis of mouse testis cell lysate with rabbit antisera 4747 and 4779 . (P) Preimmune. Approximate molecular weight standards in $\mathrm{kD}$ are shown at the left.

pression in a specific cell type or stage in testis, we probed an immunoblot containing protein isolated from purified populations of adult mouse testis with the antiAtr antisera (Fig. 3; Table 1). Atr was expressed most highly in pachytene spermatocytes, cells that are undergoing meiosis I, and its level decreased in purified cells from later meiotic stages. Low levels of Atr were detected in the round spermatid fraction. No expression was detected in the condensing spermatids or mature sperm. We interpret these results to suggest that Atr protein is expressed in the early meiotic steps and is being turned over as spermiogenesis proceeds. The small amount of Atr in the round spermatid fraction could be due to bona fide expression in this cell type, to residual protein from an earlier meiotic stage, or to contamina-

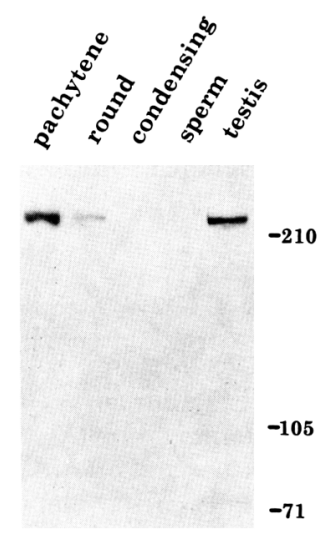

Figure 3. Atr protein level varies with the stage of meiosis. Immunoblot analysis of purified populations of spermatogenic cells. Pachytene spermatocytes and round chromatids were at least $85 \%$ pure. The condensing spermatid population was 40 $50 \%$ pure (contaminating material primarily anucleated residual bodies and some round spermatids). Sperm were obtained from the cauda epididymides. Molecular weight standards are shown at the left (in $\mathrm{kD}$ ).
Table 1. Meiotic expression pattern of mammalian Atr protein

\begin{tabular}{|c|c|c|}
\hline Cell tvpe & $\begin{array}{l}\text { Meiotic stage } \\
\text { or function }\end{array}$ & $\begin{array}{l}\text { Atr } \\
\text { protein }\end{array}$ \\
\hline Leydig cells & interstitial cells & - \\
\hline $\begin{array}{l}\text { Basement } \\
\text { membrane }\end{array}$ & $\begin{array}{l}\text { surrounds seminiferous } \\
\text { tubule }\end{array}$ & - \\
\hline Sertoli cell & compartmentalization & - \\
\hline Spermatogonia & mitotic & - \\
\hline $\begin{array}{l}\text { Primary } \\
\text { spermatocytes }\end{array}$ & $\begin{array}{l}\text { M I, recombination, and } \\
\text { synapsis }\end{array}$ & + \\
\hline $\begin{array}{l}\text { Secondary } \\
\text { spermatocytes }\end{array}$ & M II & - \\
\hline Spermatids & early sperm cell & $-{ }^{a}$ \\
\hline Spermatozoa & sperm cell & - \\
\hline
\end{tabular}

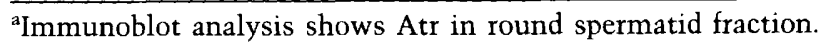
This may reflect expression of Atr in early stages of spermiogenesis or contamination of this fraction with zygotene spermatocytes.

tion of this fraction with zygotene spermatocytes. Regardless, these data demonstrate that Atr expression in testes was restricted to cells that were in meiotic prophase. Atr expression in meiotic cells is consistent with the elevated levels of $M E C 1$ transcript reported in budding yeast meiosis (Kato and Ogawa 1994), the requirement for Meclp in establishing a meiotic checkpoint, and the elevated expression of Mei-41 in Drosophilia ovaries (Hari et al. 1995).

To more precisely define the cell types that express Atr, sections of mouse testes were examined by immunohistochemical staining. Testes contain seminiferous tubules that are mainly composed of the seminiferous epithelium (a complex stratified epithelium containing the spermatogenic cells) and structural Sertoli cells. The spermatogenic cells are at various stages of meiotic differentiation. The most immature cells are peripherally localized nearest to the basement membrane, and as cells undergo spermatogenesis, they move toward the lumen of the tubule. Testicular sperm are released from the seminiferous epithelium into the lumen of the tubule. There are several morphologically distinct stages in spermatogenesis. Spermatogonia are mitotically dividing stem cells that line the basal lamina. Cells undergoing meiosis are the primary spermatocytes (meiosis I) and secondary spermatocytes (meiosis II); those undergoing condensation and differentiation into spermatozoa are early and late spermatids (Fig. 4A). Consistent with the immunoblot analysis, Atr protein was expressed highly in the primary spermatocytes (Fig. 4; Table 1) and is not present in round spermatids. This analysis also enabled us to determine the subcellular localization of Atr. Nuclear Fast Red, a nuclear counterstain, colocalized with the immunogold stain, establishing the presence of Atr in the nuclei of the cells in meiosis I (Fig. 4B). To our knowledge this is the first localization of a mammalian checkpoint homolog to the nuclei of early meiotic cells. 
A
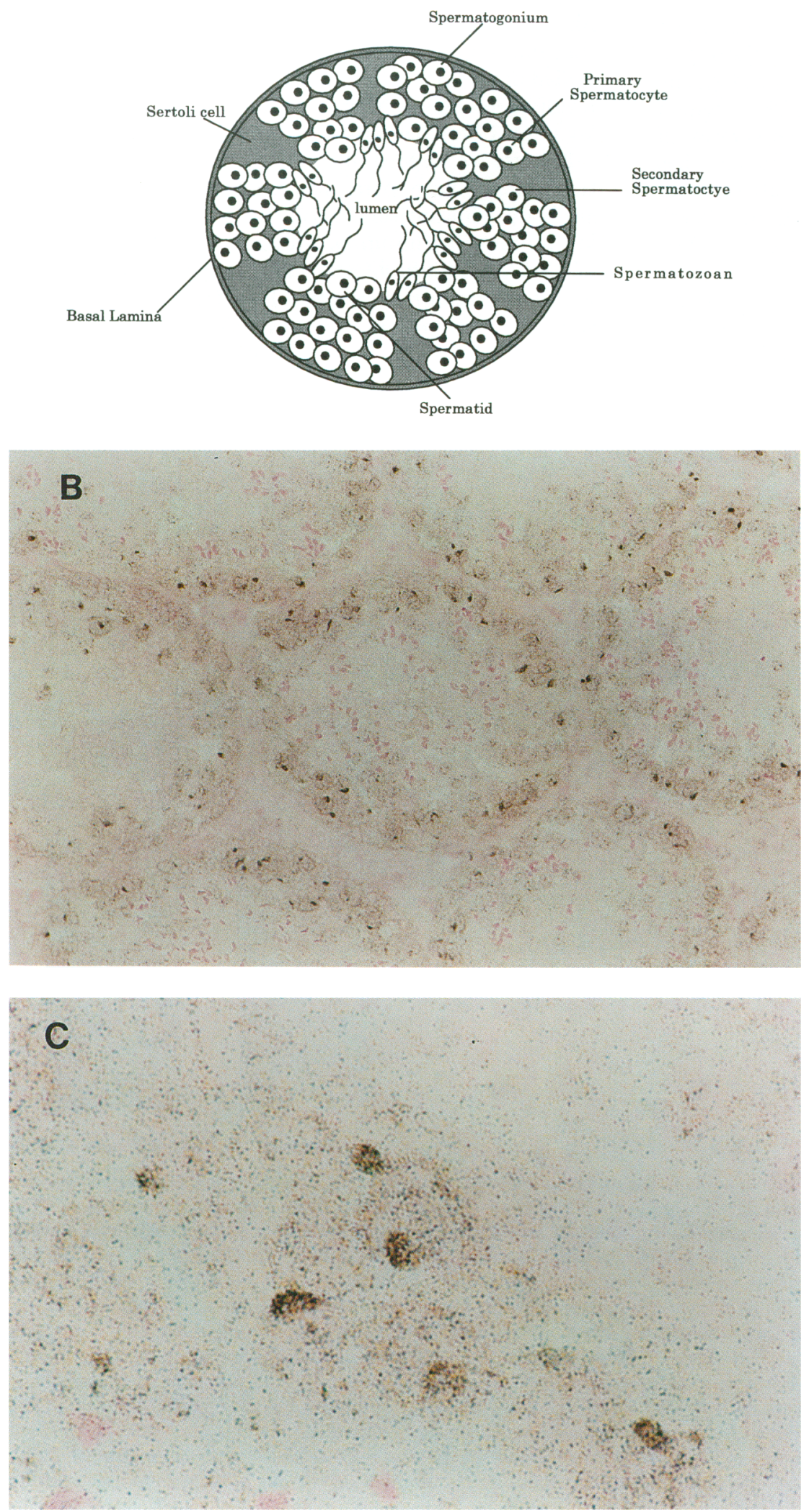

Figure 4. Atr is a nuclear protein that is expressed during meiosis I. (A) Schematic representation of a cross-section of a seminiferous tubule showing spermatogenic cell types and their relative position within the tubule. (B) A cross-section of a mouse seminiferous tubule stained with the Atr carboxy-terminal antisera 4779 and detected with immunogold (shown at $10 \times$ magnification). The dense, brown particles represent staining with 4779. (C) Enlargement of a section of the mouse seminiferous tubule showing colocalization with the nuclear counterstain, nuclear fast red $(60 \times$ magnification). 
These results suggest that Atr may be involved in establishing checkpoints in meiotic cells.

\section{Atr and Atm have associated protein kinase activity}

While the structure of the kinase domain in the Rad3 subgroup of proteins is related to the lipid kinases, proteins with this domain function as protein kinases. The best-characterized example of this is DNA-PK $\mathrm{CS}_{\mathrm{CS}}$, which phosphorylates a wide range of protein substrates in vitro (Anderson and Lees-Miller 1992) but, to date, has not been shown to phosphorylate lipids (Hartley et al. 1995). The lipid kinases, Vps34p (Stack and Emr 1994), the p110 subunit of Pl3-kinase (Carpenter et al. 1993; Dhand et al. 1994), and Frap (Brown et al. 1995) have protein kinase activity. Therefore, we tested Atr for protein kinase activity. Immunoprecipitation of an adult mouse testis extract with anti-Atr antisera followed by a protein kinase assay demonstrated clearly the presence of several phosphorylated proteins (Fig. 5A). The major phosphorylated protein in the reaction comigrated with Atr and was blocked by the fusion protein to which the antisera were made. Other phosphorylated species are likely to represent phosphorylation of proteins present in the immune complex. Phosphoamino acid analysis revealed serine phosphorylation (data not shown). These results demonstrate that Atr, like $S$. pombe Rad3 (Bentley et al. 1996), has associated protein kinase activity.

Because we wanted to compare and contrast the functions of Atr with Atm, we generated an Atm-specific antibody. This antisera, 6076, was reactive with a $\sim 350$ $\mathrm{kD}$ protein in immunoprecipitates of $\left[{ }^{35} \mathrm{~S}\right]$ methioninelabeled MRC-5 fibroblasts, and this species was blocked with the immunizing peptide P45 (Fig. 5B). In comparisons, the Atm protein migrates $\sim 50 \mathrm{kD}$ larger than Atr from ${ }^{35}$ S-labeled lysates (E. Christenson, unpubl.), con-

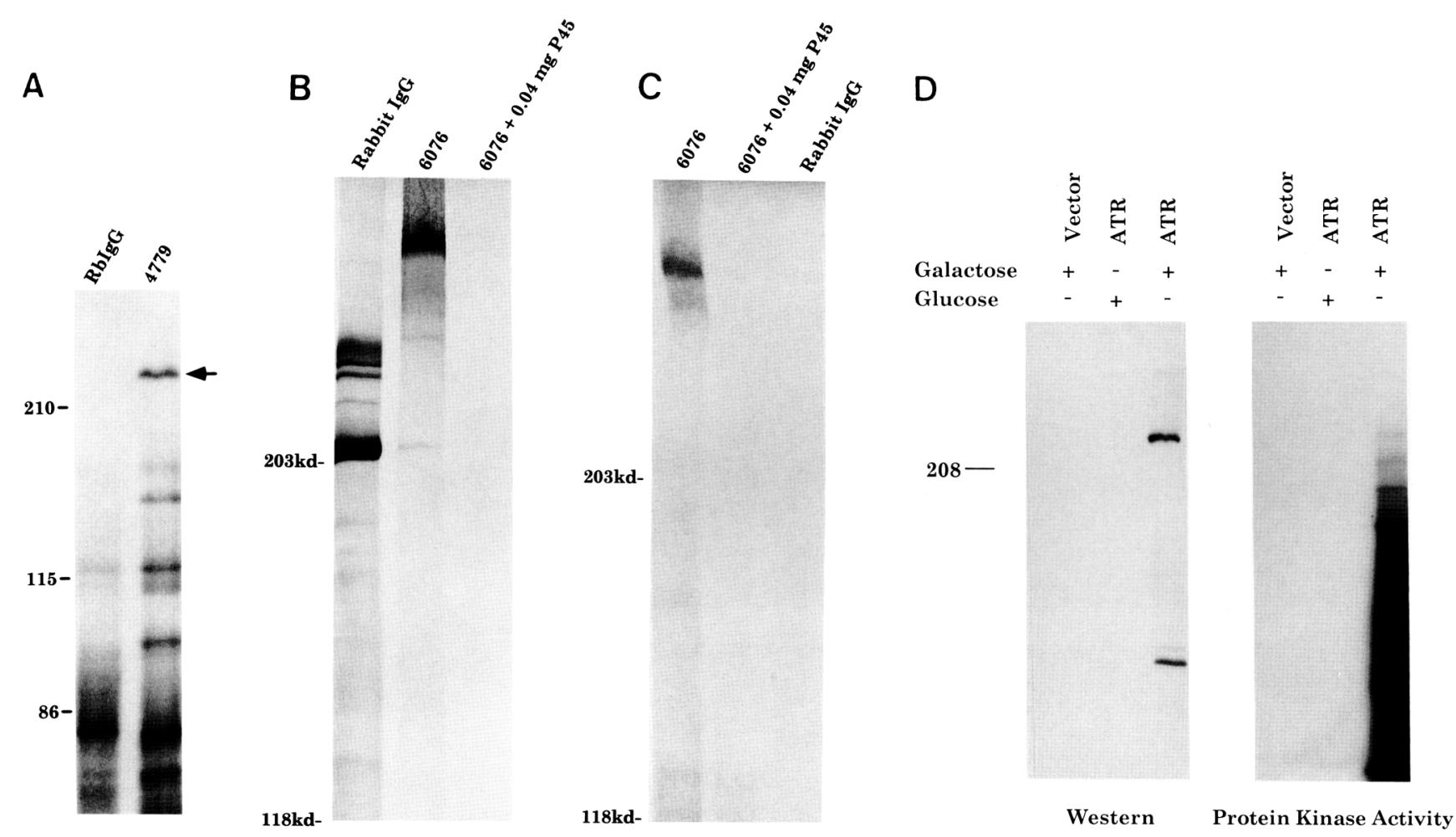

Figure 5. Atr and Atm have associated kinase activity. $(A)$ Atr has associated kinase activity. An immunoprecipitation of a mouse testes cell lysate with either a nonimmune rabbit IgG (RbIgG) or 4779 was carried out followed by a protein kinase assay. The phosphorylated protein indicated by the arrow was shown by immunoblot analysis to comigrate with Atr. $(B)$ The anti-Atm peptide antibody recognizes a $\sim 350-\mathrm{kD}$ molecular weight protein in $\mathrm{MRC}-5$ cells. Immunoprecipitation of $\left[{ }^{35} \mathrm{~S}\right]$ methionine-labeled human diploid fibroblasts was performed using rabbit IgG (as a negative control), the Atm antisera, 6076, or 6076 preincubated with 0.04 mg of the peptide against which it was made (P45). (C) Atm has an associated protein kinase activity. Immunoprecipitation with rabbit IgG, 6076, or 6076 preincubated with the peptide against which the antisera was made (P45), washed and incubated with ${ }^{32} \mathrm{P}-\gamma \mathrm{ATP}$ in the presence of kinase buffer. The numbers at the left signify the approximate molecular weights of protein standards (in $\mathrm{kD}) .(D)$ His-tagged Atr expressed in S. cerevisiae shows protein kinase activity. His-tagged Atr expression under the control of the GAL1 promoter was induced by the addition of galactose or repressed by growth in glucose. Either vector alone or vector containing the full-length, his-tagged Atr were grown in the presence or absence of glucose or galactose as indicated by $(-)$ or $(+)$. Atr was purified on $\mathrm{Ni}^{+}$-affinity resin and assayed for protein kinase activity (right). The presence of Atr was followed by immunoblot analysis (left). The lower molecular weight proteins are likely to represent degradation products. The number on the left indicates the approximate molecular weight of the standards (in $\mathrm{kD}$ ). 
firming the size difference of Atm and Atr predicted from their open reading frames and the specificity of both Atm and Atr antisera. Furthermore, the anti-Atm sera immunoprecipitates truncated Atm proteins from cell lines derived from A-T patients that contain termination codon mutations (E. Christenson, unpubl.). Immunoprecipitation using anti-Atm antisera followed by a protein $\mathrm{ki}$ nase assay (Fig. $5 \mathrm{C}$ ) showed ${ }^{32} \mathrm{P}$ incorporation into the same $\sim 350-\mathrm{kD}$ protein that was immunoprecipitated in $\left[{ }^{35} \mathrm{~S}\right]$ methionine-labeled cells, demonstrating that Atm also has an associated protein kinase activity. This protein kinase activity is missing in A-T cell line AT7LA (Wright et al. 1996), which contains a termination codon mutation amino terminal to the Atm protein kinase domain (E. Christenson, unpubl.).

The immunoprecipitation and protein kinase assays for Atr and Atm reveal that both proteins have an associated protein kinase activity. Both DNA-PK $\mathrm{Cs}_{\mathrm{C}}$ and FRAP have been shown to autophosphorylate in the absence of any associated cofactors (Lees-Miller et al. 1990; Dvir et al. 1993; Brown et al. 1995). To extend our analysis of the protein kinase activity of Atr, we expressed this protein in $S$. cerevisiae as a His-tagged protein and purified the protein using $\mathrm{Ni}^{+}$-affinity resin. As observed for immunoprecipitations from cell extracts, $\mathrm{Ni}^{+}$-His-affinity purified Atr contains protein kinase activity (Fig. 5D). While these results do not rule out the presence of associated proteins, affinity purification of the His-tagged Atr from yeast demonstrates that protein expressed in a heterologous system also shows kinase activity. Thus we have demonstrated that Atr that has been partially purified by two independent means show an associated kinase activity.

DNA-PK ${ }_{\mathrm{CS}}$ has been shown to phosphorylate a wide variety of proteins, including p53, RPA, and casein (Anderson and Lees-Miller 1992). Because there is structural similarity between Atr, Atm, and DNA-PK ${ }_{\mathrm{CS}}$, we tested whether there was any overlap in substrate specificity. Neither immunoprecipitated Atr nor Atm phosphorylated purified RPA, and Atr did not phosphorylate a peptide from p53 that contained the DNA-PK $\mathrm{PS}_{\mathrm{Cs}}$ phosphorylation site. However, Atr showed a three- to fivefold increase in casein phosphorylation (data not shown), suggesting that there may be some overlap in substrate specificity. These observations suggest that the proposed role for Atm and Rad3-like proteins such as Atr in p53 and RPA effector phosphorylation may occur through an intermediate protein kinase like Rad53p (Carr 1996).

\section{Atr and Atm proteins associate with meiotic chromosomes}

If Atm and Atr are involved in establishing the meiosis I checkpoints, it may be possible to elucidate their functions by studying their localization. The size of the mammalian genome, the degree of compaction of the genetic material at meiosis, and the relatively slow rate of progression of spermatocytes through meiosis I allows the spatial and temporal localization of proteins and can indicate the sites and timing of their activity (Ashley et al. 1995). We have used immunostaining techniques on surface spreads of mouse spermatocytes to localize Atm and Atr to meiotic chromosomes (Figs. 6-8). Rabbit antibodies recognizing Atr and Atm were colocalized with mouse antibodies against Corl to assist us in timing and substaging meiotic events. Corl is a component of axial/ lateral elements of synapsing chromosomes (Dobson et al. 1994). Corl chromosomal staining appears when the axial elements begin to form between the sister chromatids of each homolog in leptonema of meiotic prophase, prior to the initiation of synapsis (Dobson et al. 1994). As homologous bivalents synapse, the axial elements from the two homologs align and a central element forms between them, completing the structure called the synaptonemal complex (SC).

When short stretches of Cor1 begin to appear prior to any evidence of synapsis, neither Atr nor Atm is detectable. As homologs start synapsis, both proteins are seen at pairing forks; however, the location and behavior of the two proteins differ markedly. In normal zygotene nuclei, the stage during which homologs synapse, Atr is present in small amounts and transiently at discrete foci along the asynapsed (unpaired) axes. As homologs synapse, Atr disappears from these locations. However, at regions delayed in synapsis, often seen near the proximal ends of autosomal bivalents, there was an accumulation of Atr foci along the unsynapsed axes. Atr is detected at similar locations on the two axial elements. In nuclei where an entire autosome fails to find its homologous pairing partner, Atr foci were detected along the entire lengths of these asynapsed axes. In males, where the $\mathrm{X}$ chromosome has no homolog, Atr foci were localized along the unpaired axis (Fig. 8).

Atm is also visualized as foci and is first detected during zygonema as homologs synapse (Fig. 7). The Atm localization is different than Atr (Fig. 8). Atm is first observed along synapsed axes when homologous autosomal axial elements come into contact. However, during mid-pachynema, after autosomal synapsis has been completed, Atm foci appear on the $\mathrm{X}$ chromosome axis (data not shown). Atm localization persists on fully synapsed bivalents into pachynema, a substage that lasts 3 days in mouse oocytes and 6 days in mouse spermatocytes. During pachynema, the number of foci drops gradually, stabilizing briefly in mid-pachynema before eventually disappearing mid- to late pachynema. These data indicate important and complementary roles for the Atr and Atm protein kinases at distinct stages in meiosis I.

\section{Discussion}

Atr is a mammalian counterpart of Rad3, Mec1p, and Mei-41

We have characterized a mammalian Rad3, Meclp, Mei41 and Atm-related protein, Atr. This protein is more homologous to the Rad3, Meclp, and mei-4l checkpoint proteins than it is to the Atm protein (Bentley et al. 1996; Cimprich et al. 1996), whereas Tellp is more re- 

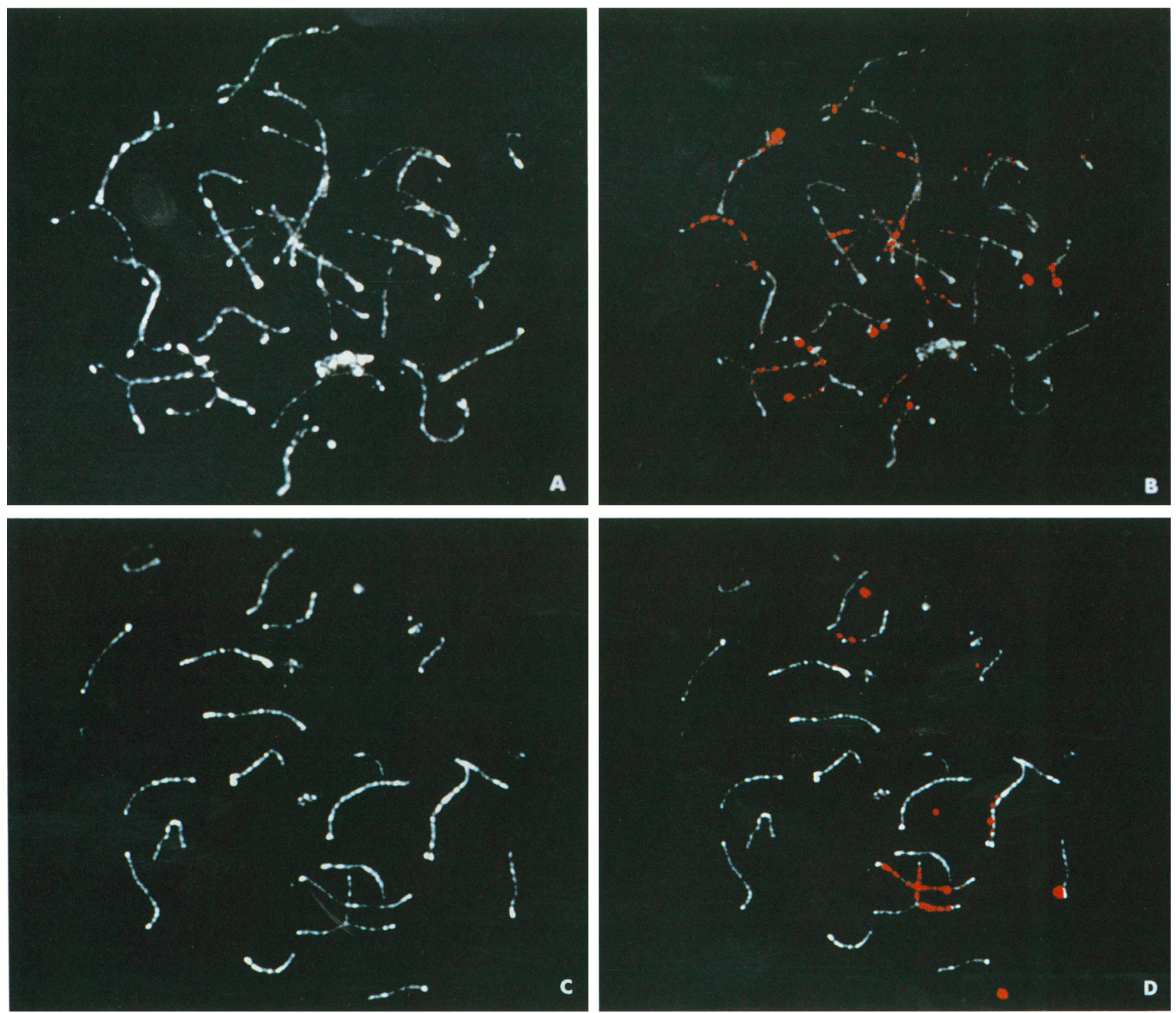

Figure 6. Atr localization on meiotic chromatin. Immunofluorescence localization of ATR in meiotic prophase of spermatocytes of mouse. $A$ and $C$ show the localization of Corl, a component of the axial elements of the synaptonemal complex (SC), and $B$ and $D$ show the merged Corl (white) and Atr (red) images. ATR localizes to sites along unsynapsed axes in zygonema $(B)$ and pachynema $(D)$. The unpaired axes of a partially synapsed autosome in early pachynema $|D|$ have Atr foci, as does the unpaired $\mathrm{X}$ axis shown at higher magnification in Fig. 8.

lated to Atm (Bentley et al. 1996). rad3 and MEC1 control the $\mathrm{G}_{2}-\mathrm{M}$ DNA damage checkpoints in response to UV and ionizing radiation and the S-phase checkpoint following inhibition of DNA replication (Al-Khodairy and Carr 1992; Weinert et al. 1994; Paulovich and Hartwell 1995). In contrast, cells derived from A-T patients are sensitive to a subset of the DNA-damaging agents in comparison to yeast cells that lack $\operatorname{Rad} 3$ function (Jimenez et al. 1992; Beamish and Lavin 1994; Bentley et al. 1996). The Atm protein controls the checkpoints that respond to a narrow range of DNA damaging agents, all of which produce DNA strand breaks as a consequence of free-radical attack. The response of A-T cells to UV and certain chemical carcinogens is normal as is the re- sponse to inhibition of DNA synthesis. In addition, we report that Atr and Atm, like MEC1 (Kato and Ogawa 1994) and mei-41 (Baker and Carpenter 1972; Baker et al. 1976; Hari et al. 1995), appear to play a role in meiosis. These observations suggest that Atr is a mammalian checkpoint protein with analogous function to the Rad3 proteins and shares complementary functions with Atm in human cells. The definition of precisely which checkpoints are dependent on Atr function in mammalian cells awaits the availability of Atr-deficient cells.

\section{Atr and Atm have associated protein kinase activity}

The protein kinase activity associated with Atm and Atr 

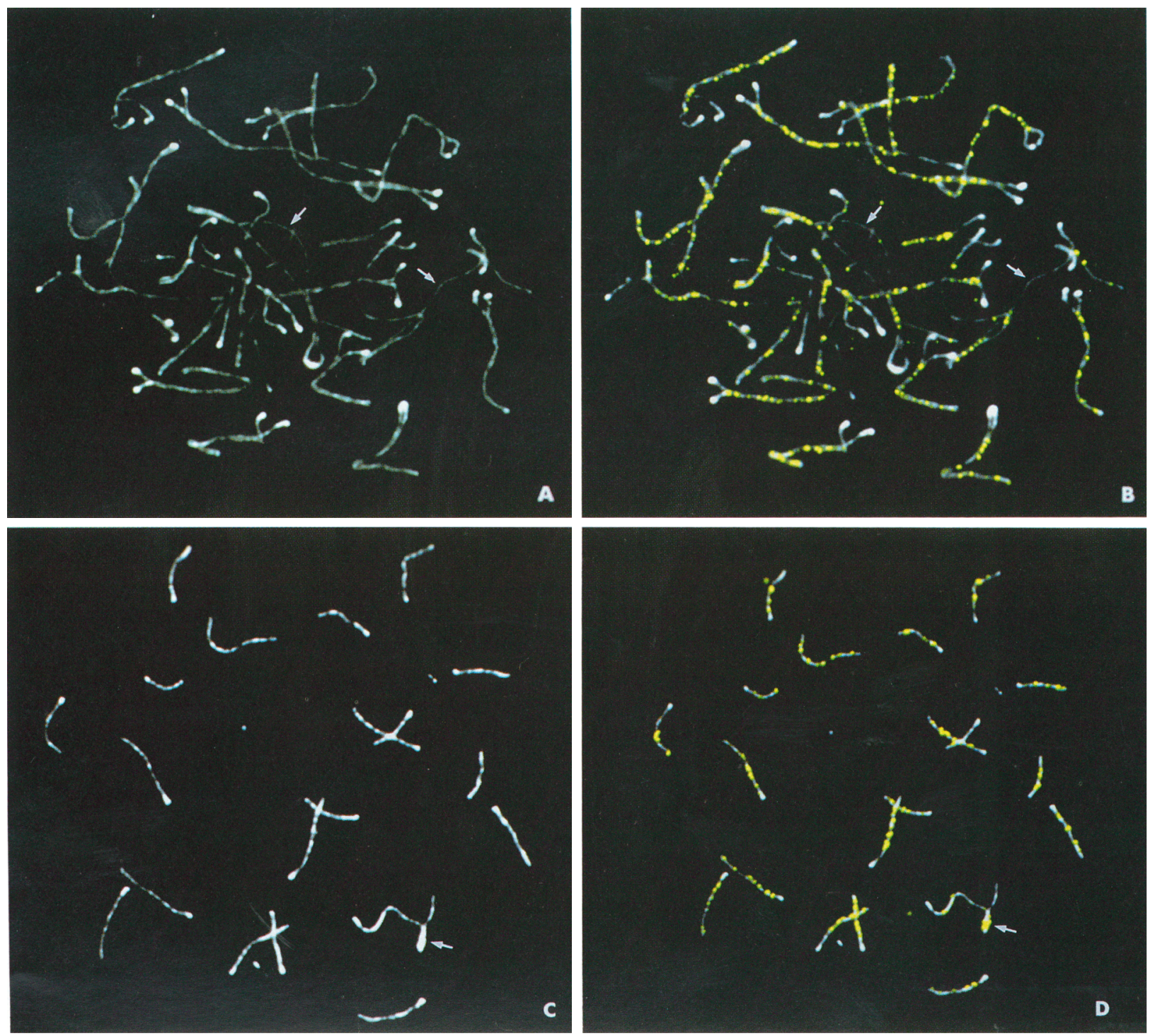

Figure 7. Atm localization on meiotic chromatin. Immunofluorescence localization of ATM in meiotic prophase of mouse oocytes $(A, B)$ or spermatocytes $(C, D)$. A and $C$ show the localization of Corl, a component of the axial elements of the synaptonemal complex (SC), and $B$ and $D$ show the merged Corl (white) and Atm (yellow-green) images. Atm localizes to synapsed axes only. By late zygonema in oocytes $(A$ and $B)$ pairing is proceeding. Atm foci are found along the entire lengths of the synapsed axes, but not the asynapsed axes (small arrow, $B$ ). In pachynema in spermatocytes $(C$ and $D \mid$, Atm foci are present along the synapsed autosomal axes and the paired portion of the XY (small arrow, D). In addition, two small foci are regularly observed on the unpaired axis of the $\mathrm{X}$ chromosome at this substage of pachynema.

may result from an intrinsic protein kinase activity of these molecules; however, we are unable to rule out the presence of an associated protein kinase in our immunoprecipitates. Possession of intrinsic protein kinase activity is consistent with the model of a checkpoint signal transduction cascade (Carr 1996). The presence of protein kinase domains in Atm and Atr make these molecules ideal candidates as sensors of aberrations in DNA structure. Detection of DNA damage or an incorrect DNA structure by Atm or Atr could stimulate the protein kinase activity of these proteins, thereby initiating a cascade leading to cell-cycle arrest and then, ultimately,
DNA repair, apoptosis, or cellular senescence in mitotic cells or genetic recombination, chromosome pairing, and segregation in meiotic cells. While the structure of the kinase domains of these two proteins is related most highly to lipid kinase domains, it is known that proteins with this domain are able to act as protein kinases and that DNA-PK $\mathrm{CS}$ and FRAP are able to autophosphorylate independent of associated regulating subunits (Dvir et al. 1993; Brown et al. 1995). DNA-PK ${ }_{\mathrm{Cs}}$ phosphorylates a wide range of proteins in vitro; however, it has not been shown to phosphorylated lipids (Hartley et al. 1995). Rad3 has associated protein kinase activity and mutants 


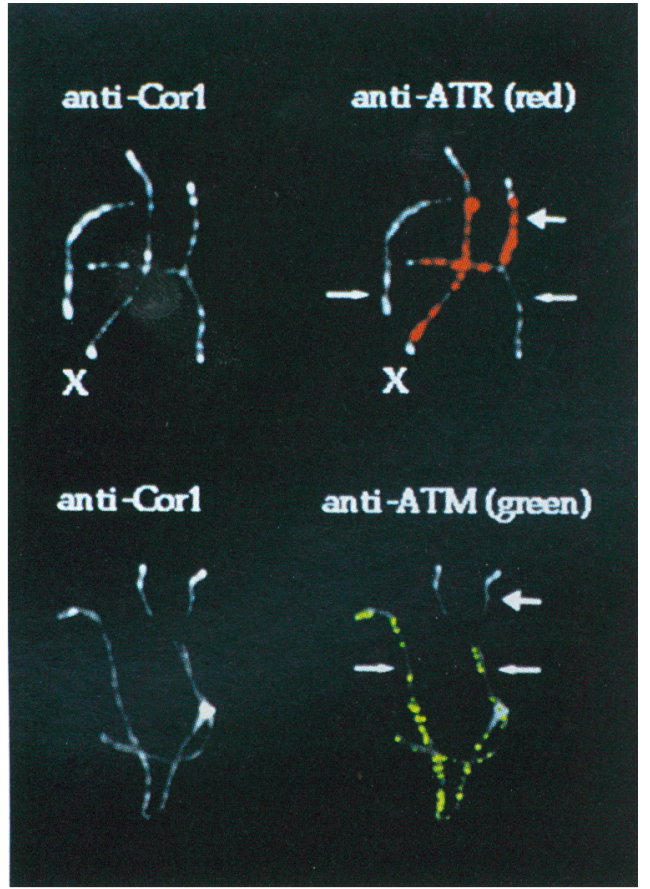

Figure 8. Atr and Atm show complementary localization along unpaired (Atr) and paired (Atm) axes. The Corl images are shown at left; the merged Corl plus Atr (red) at upper right and Corl plus Atm (yellow-green) at lower right. The Atr enlargement shows a completely synapsed autosomal bivalent on the left, the univalent $\mathrm{X}$ in the center, and a partially synapsed autosomal bivalent on the right. The synapsed portions (small arrows) of the autosomes have no Atr foci, while the asynapsed portions of the autosomal axes (large arrow) and the $\mathrm{X}$ axis have foci along their lengths. In the lower set of images there is a completely synapsed autosomal bivalent (left) and a partially synapsed autosomal bivalent (right). Atm foci are found only on the synapsed axes (small arrows), not on the asynapsed axes (large arrows).

in the protein kinase domain that render the kinase inactive are defective for checkpoint function (Bentley et al. 1996). In addition, Frap and Vps34 autophosphorylate (Stack and Emr 1994; Brown et al. 1995).

We have been unable to observe phosphorylation of proteins known to be substrates for DNA-PK $\mathrm{Cs}_{\text {such as }}$ RPA or a 553 peptide containing the DNA-PK site. However, there are other proteins that may be potential substrates of Atr or Atm and these substrates have been suggested to be protein kinases. In fission yeast, phosphorylation of the Chk1 protein kinase, which is required for the mitotic arrest after DNA damage, has been shown to depend on a functional rad3 gene (Walworth and Bernards 1996). The S. cerevisiae RAD53 gene, which encodes another protein kinase, is a multicopy suppressor of mec1 lethality (Sanchez et al. 1996), and mec1 mutants lack Rad53p hyperphosphorylation. Further, overexpression of the ATM homolog, TEL1 in a mec1 strain restores Rad53p phosphorylation (Sanchez et al. 1996). Identification of the mammalian homologs of these downstream effectors for Rad3 and Meclp will allow us to determine whether they act as substrates for Atm and Atr. These will be key to understanding the pathways leading from DNA damage and DNA structural aberration to cell-cycle arrest and to the meiotic function of these proteins.

\section{Atr is a nuclear protein expressed in early meiotic cells}

We have demonstrated that Atr is expressed in cells in early meiotic prophase. Many of the checkpoint proteins identified in yeast as being required for the mitotic arrest after DNA damage or S-phase arrest (for review, see Carr and Hoekstra 1995) are also required for the checkpoints that function during meiosis. The checkpoint genes $M E C 1$ (Weber and Byers 1992; Kato and Ogawa 1994) and mei-41 (Baker and Carpenter 1972; Baker et al. 1976; Hari et al. 1995) and DNA repair genes such as MLH1 (Baker et al. 1996; Edelmann et al. 1996) and the RAD50RAD57 series (Petes et al. 1991; Friedberg et al. 1995) have been shown to play roles in meiotic processes. For yeast, it has been suggested that meiotic recombination is initiated by DSBs (for review, see Roeder 1990; Kleckner 1996) and involves strand invasion and repair synthesis. This potential role for DSBs as initiating lesions for meiosis I recombination would predict a requirement for checkpoint and repair proteins in signaling DSBs and /or repair synthesis during meiotic prophase. An alternative model of synaptic initiation in multicellular eukaryotes suggests that a subfraction of the eukaryotic genome is not replicated in the premeiotic $S$ phase, but is delayed until zygonema (for review, see Stern and Hotta 1984), thus the function of checkpoint proteins during zygonema could be to monitor the completion of DNA replication before further meiotic progression. In this model nicks or breaks in DNA may not occur until a check for homology is completed.

\section{Complementary roles for Atr and Atm in meiosis}

We have demonstrated that both Atr and Atm form foci at discrete sites along meiotic chromosomal axes as homologs synapse. The involvement of Atr appears to be transient and restricted to an early event in the synaptic process. In fact, in zygotene nuclei, the interaction appears to be sufficiently transient that Atr detection at many pairing forks is low. One interpretation is that a small amount of Atr is present, and then only briefly. Alternatively, Atr localization to chromosomes may be absent when chromosome synapsis is proceeding normally. In support of this second explanation, Atr appears to accumulate at autosomal pairing sites where synapsis has been delayed. Since the X chromosome has no homolog in spermatocytes, it can never undergo completely homologous synapsis, although it undergoes a small amount of homologous synapsis and extensive nonhomologous synapsis with the $\mathrm{Y}$ chromosome. We find that Atr remains on the asynapsed $\mathrm{X}$ axis into 
pachynema (Fig. 8). These results suggest that Atr may play a role in monitoring asynapsis of chromosomes.

While the role for Atr in early meiotic prophase is transient, the role for Atm is more prolonged. Atm associates with axes as they synapse, producing multiple foci along these axes. It appears likely that those Atm foci seen in zygonema and early pachynema may reveal a participation in events associated with synapsis. However, some Atm foci are present in mid-pachynema, the stage at which reciprocal recombination is thought to occur, suggesting Atm may be involved in both synaptic and recombination events.

The time of appearance of Atr and Atm in zygotene nuclei, along with the localization of Atr at sites along unpaired chromosomal axes, and Atm along paired axes, suggest they are both involved in the synaptic process. Although there is evidence that the meiotic search for homology is initiated by DSBs and accomplished by gene conversion events in yeast (Sun et al. 1989; Cao et al. 1990; Bishop 1994), this may not be the sequence of events in multicellular eukaryotes (Plug et al. 1996). The check for homology in mouse may precede breakage and gene conversion events (Plug et al. 1996), and our current observations are consistent with this suggestion. When $\mathrm{Xu}$ et al. (this issue) disrupted the Atm gene they found fragmentation of synaptonemal complex axes, but not until later in meiotic prophase, suggesting that unrepaired breaks could be a secondary, not primary consequence of Atm disruption. In this model, Atr would be predicted to be monitoring breaks associated with a search for homology. An unsuccessful search (with unrepaired breaks) should result in fragmentation of univalent axes. While univalent axes accumulate Atr (Figs. 6 and 81, they do not fragment, suggesting that breaks may not have yet occurred.

Atr and Atm may play essential, but indirect, roles in meiosis. In mitotic cells, Atm is required for a DNA damage-dependent signal transduction cascade that activates multiple cell-cycle checkpoints (Meyn 1995; Shiloh 1995). In yeast and flies, Atr-like proteins are important for DNA damage and replication-like checkpoints. In spermatocytes, Atr and Atm may help coordinate the various events of meiotic prophase by performing similar checkpoint functions. Early meiotic prophase checkpoints would be predicted to signal breaks and monitor repair synthesis as well as coordinately monitor homologous synapsis and DNA replication before further meiotic progression. The Atr- and Atm-dependent signal transduction networks could be triggered by DSBs and/ or related structures occurring in synapsing meiotic chromosomes. Alternatively, Atr may control an S-phase meiotic checkpoint that responds to single-stranded regions of DNA, whereas Atm may recognize direct DNA strand lesions during recombination processing events.

The focal pattern of Atr along the asynapsed axes, and of Atm along the synapsed axes, is similar to the focal pattern described for hRad51 (Ashley et al. 1995). Recent work has suggested that during early meiotic prophase Rad51 is a component of early recombination nodules (RNs), thought to be involved in the check for homology and synaptic initiation (Bishop 1994; Ashley et al. 1995; Terasawa et al. 1995). The time of appearance of Rad51p in yeast appears to coincide with the time of appearance of both DSBs and SC precursors (Bishop 1994). Rad51 in mammals associates with chromosomes as early as premeiotic S phase, before the appearance of SC precursors (Plug et al. 1996). We find no evidence that either Atr or Atm are present on chromosomes at this stage. Atr and Atm foci appear as homologous chromosomes begin to synapse. The staining sites on synapsing chromosomes appear to correspond to similar sites of Rad51 distribution in mammalian spermatocytes and oocytes.

While the location of Atr and Atm along meiotic chromosomal axes is similar to the focal pattern of hRad51 along axes of synapsing and synapsed chromosomes, the timing and appearance and disappearance of each of these proteins differs, indicating a dynamic nature and suggesting multiple activities for these protein complexes. The pattern of association of Atr and Atm with meiotic chromatin is consistent with each playing separate roles in monitoring DNA structure or behavior during early synaptic and recombination events.

\section{Materials and methods}

\section{Northern blot hybridization}

A 1.3-kb PCR product was amplified in the presence of ${ }^{32} \mathrm{P}$ dCTP using primers 279-3 (TGGATGATGACAGCTGTGTC) and 279-6 (TGTAGTCGCTGCTCAATGTC). A nylon membrane containing $2 \mu \mathrm{g}$ of size-fractionated poly $\mid \mathrm{A})^{+}$RNA from a variety of human tissue sources (Clontech Laboratories) was probed with the labeled PCR fragment described above as recommended by the manufacturer except that the final wash was performed at $55^{\circ} \mathrm{C}$ to minimize the possibility of cross-hybridization to related sequences. A mouse CDNA clone was isolated by low-stringency hybridization. Oligonucleotides mrad3-1 $15^{\prime}-$ CGAGATCCATTGTGCTGGAAAGG-3') and mrad3-2 (5'-CTGCAGTAGAGCGGCAATATGC-3') were used to produce an $\sim 300$-bp probe as above that was used for hybridization of a Northern blot containing $2 \mu \mathrm{g}$ of poly $\mid \mathrm{A})^{+}$RNA from a variety of mouse tissues and from total embryos at days $7,11,15$, and 17 as described above.

\section{Cell lines and media}

MRC- 5 cells were obtained from the ATCC at passage 19 and maintained in Minimal Essential Medium (MEM) supplemented with $10 \%$ fetal bovine serum, 100 units $/ \mathrm{ml}$ penicillin, and $100 \mu \mathrm{g} / \mathrm{ml}$ streptomycin, and $100 \mu \mathrm{M}$ MEM nonessential amino acids. 293T were maintained in MEM with the supplements listed above. G361 were maintained in McCoy's 5A containing $10 \%$ fetal bovine serum and 100 units $/ \mathrm{ml}$ penicillin and streptomycin. Media and media supplements were obtained through Gibco Life Technologies. Cell lines were maintained in a water-saturated $37^{\circ} \mathrm{C}$ incubator with $5 \% \mathrm{CO}_{2}$.

\section{Antibody preparation}

Atr-antibodies to two different glutathione-S-transferase (GST) fusion proteins were generated in rabbits. Antigen DH-2 (4779) contains Atr amino acid residues 2341 to 2644 fused to GST in pGEX1. Antigen DH-3 (4747) contains Atr residues 1892 to 2340 fused to GST in pGEX3 (Pharmacia). Antigens were gel-purified 
by SDS-PAGE and electroelution and used to immunize rabbits. Antibodies were affinity purified with inclusion body preparations of antigen coupled to cyanogen bromide-activated Sepharose (Pharmacia) as per manufacturer's instructions. Both antisera immunoprecipitate an associated kinase activity that is blocked by the antigen against which the antibodies were generated.

Antipeptide antibodies were generated against the human Atm protein by coupling a 15-amino-acid peptide (residues 1359-1373) to Keyhole Limpet Hemocyanin (KLH) using 1-ethyl-3-[dimethylaminopropyl]-carbodimide hydrochloride (EDC) as described by the manufacturer (Pierce), followed by injection of the coupled immunogen into rabbits. The antibodies were first precipitated from the serum $(\# 6076)$ with an equal volume of saturated ammonium chloride followed by resuspension and dialysis against PBS. Affinity purification was carried out using a peptide column prepared by coupling the antigenic peptide to $\mathrm{CNBr}$-activated Sepharose (Pharmacia) as described by the manufacturer. The antibodies were then bound to the peptide column and washed with $2 \mathrm{M} \mathrm{KCl-PBS}$. Elution was carried out with $20 \mathrm{ml} 5 \mathrm{M} \mathrm{NaI}$ (in $1 \mathrm{~mm}$ sodium thiosulfate), which was dialyzed immediately against PBS. Specificity for the Atm sera was examined by immunoblot analysis using recombinant Atm and by immunoprecipitation of ${ }^{35} \mathrm{~S}$-labeled lysates. Anti-Atm and anti-Atr recognize different sized proteins that migrate at the predicted molecular mass for Atm and Atr when compared from the ${ }^{35} \mathrm{~S}$-labeled lysates.

The ATMl antibody, used for staining of surface spreads, was generated against the Atm protein by coupling a 14-amino-acid peptide (residues 1347-1360) to $\mathrm{KLH}$, followed by injection of the coupled immunogen into New Zealand white rabbits. Antibodies were purified using protein A agarose and tested for anti-Atm reactivity by immunoblotting against extracts of Daudi and Hela cells (positive controls) and the A-T lymphoblast line ATF169 (negative control). ATM1 was provided by Dave Hill (Oncogene Research, Products/Calbiochem, San Diego, CA).

\section{Immunoprecipitations and kinase assays}

Cell extracts were prepared by lysing in lysis buffer $[50 \mathrm{mM}$ $\mathrm{NaPO}_{4}$ at pH 7.2, 0.5\% TritonX-100, 2 mM EDTA, 2 mM EGTA, $25 \mathrm{~mm} \mathrm{NaF}, 25 \mathrm{~mm}$ 2-glycerophosphate, $1 \mathrm{~mm}$ phenylmethylsulfonyl fluoride (PMSF) $1 \mu \mathrm{g} / \mathrm{ml}$ leupeptin, $1 \mu \mathrm{g} / \mathrm{ml}$ pepstatin $A$, and 2 mM DTT]. Mouse testes extracts were prepared by dounce homogenization of decapsulated testes in lysis buffer followed by centrifugation at 10,000g. For Atr IPs, $500 \mu \mathrm{g}$ of extract was incubated with either $10 \mu \mathrm{g}$ of affinity-purified 4779 antibody or $10 \mu \mathrm{g}$ purified rabbit IgG in $1 \mathrm{ml}$ of lysis buffer for $1 \mathrm{hr}$ on ice. Thirty microliters of protein A-agarose slurry (Pierce) was added and incubated for $30 \mathrm{~min}$ at $4^{\circ} \mathrm{C}$ on a rocking platform. The immune complexes were then washed $3 \times$ with lysis buffer, once with kinase buffer $(25 \mu \mathrm{M}$ HEPES at $\mathrm{pH} 7.7 ; 50$ $\mathrm{mM} \mathrm{KCl} ; 10 \mathrm{mM} \mathrm{MgCl} 2 ; 0.1 \%$ NP-40; $\%$ glycerol; $1 \mathrm{~mm} \mathrm{DTT),}$ and incubated in kinase buffer with $10 \mu \mathrm{M}$ ATP $(50 \mathrm{Ci} / \mathrm{mmol})$ plus $10 \mu \mathrm{Ci}\left[\gamma^{-32} \mathrm{P}\right] \mathrm{ATP}$ for $20 \mathrm{~min}$ at $37^{\circ} \mathrm{C}$. The reactions were stopped with $20 \mu 12 \times$ SDS sample buffer prior to separation on $6 \%$ polyacrylamide gels. Kinase reactions were then transferred to Immobilon, exposed to film, and then subsequently probed with 4779 to confirm that the phosphorylated band comigrated with Atr.

MRC-5 cell extracts were prepared by lysis of a $10-\mathrm{cm}$ plate of cells in $0.5 \mathrm{ml}$ of the above lysis buffer on ice. Cells were scraped from plates using rubber spatulas and sonicated in a cup horn sonicator (Sonifier 250, Branson Ultrasonics Corp., Danbury, CT) at $100 \%$ output for $90 \mathrm{sec}$. Lysates were then clarified in a $4^{\circ} \mathrm{C}$ microfuge for $2 \mathrm{~min}$. Preclearing was done by adding 10 $\mu \mathrm{g}$ purified rabbit IgG and $30 \mu \mathrm{l}$ protein A-agarose slurry followed by incubation at $4^{\circ} \mathrm{C}$ for $60 \mathrm{~min}$ while rocking. To the precleared lysates, $10 \mu \mathrm{g}$ of affinity purified 6076 antisera (or 10 $\mu \mathrm{g} 6076$ preblocked with $0.04 \mathrm{mg}$ peptide for $30 \mathrm{~min}$ ) was added and incubated on ice for $60 \mathrm{~min}$. Immunoprecipitates were washed and a kinase reaction was performed as described above.

\section{Expression and purification of recombinant Atr}

An ATR BamHI-Sall fragment containing an amino-terminal -His tag was cloned into the BamHI-XhoI site of the CEN-based galactose inducible yeast vector p416 GALl (gift from D. Morrow, Johns Hopkins University, Baltimore, MD). Plasmid DNA was transformed into an esr1-1 diploid yeast strain (MAT $\alpha$ leu2-1 his4-4 can1 ura3 cyh2 ade6 ade2 esr1-1/MATa leu2-27 his4 trp1 met2 ade2 esr1-1), and cells were grown to mid-log phase in either galactose or glucose containing medium. Cells were pelleted, washed, and all steps performed at $4^{\circ} \mathrm{C}$. Cell pastes were resuspended in buffer $(20 \mathrm{~mm}$ Tris at $\mathrm{pH} 8.0,300$ $\mathrm{mm} \mathrm{NaCl}, 10 \%$ glycerol, $0.1 \mathrm{~mm}$ PMSF, $0.25 \mathrm{mg} / \mathrm{ml}$ pepstatin, leupeptin, and aprotinin) and lysed in a French Press or using glass beads. Lysis was verified by microscopy following a lowspeed $(10 \mathrm{~K})$ spin and a high-speed spin $(100 \mathrm{~K})$, and the supernatant was loaded onto a 1.5-ml Ni-NTA agarose (Qiagen, Inc., Chatsworth, CA) column prewashed in $1 \times$ buffer. The column was washed with six column volumes of buffer. The column was eluted stepwise with $8 \mathrm{ml}$ of $10 \mathrm{~mm}, 50 \mathrm{~mm}, 100 \mathrm{~mm}$, and $250 \mathrm{~mm}$ imidazole in buffer. Fractions were collected and Western analysis was performed using $15 \mu$ l of each elution peak. For protein kinase assays, $2 \mu \mathrm{l}$ of the $50 \mathrm{~mm}$ imidazole elution pool was added to kinase buffer. The reactions were incubated at $37^{\circ} \mathrm{C}$ for $20 \mathrm{~min}$. Samples were analyzed by SDS-PAGE prior to autoradiography or Western analysis.

Spermatocyte preparation, immunoblot analysis, and immunocytochemistry

For tissue sections, testis tissue from Balb/c mice was sectioned, fixed in acetone, blocked with $30 \%$ rat serum, $5 \%$ goat serum, and $1 \%$ BSA before incubation with either affinity-purified 4747 or 4779 antisera, the equivalent preimmune sera, or anti-GST sera. Antibody was detected with biotinylated goat antirabbit antibody and streptavidin-gold conjugate. Sections were counterstained with nuclear fast red. Signal was detected with both 4747 and 4779 sera, but not detected with preimmune sera or antibodies to GST alone. For purified cell populations, decapsulated testes of adult CD-1 mice were dissociated sequentially with collagenase and trypsin-DNase I (Romrell et al. 1976). Dissociated cells were separated into populations by sedimentation in 2-4\% BSA gradients (Bellve et al. 1977). Pachytene spermatocyte and round spermatid populations were at least $85 \%$ pure. The condensing spermatid population was $40-50 \%$ pure (contaminating material was primarily anucleated residual bodies and some round spermatids). Sperm were obtained from the cauda epididymides. Cell populations were dissolved directly in SDS sample buffer for immunoblot analysis.

Surface spreads were prepared using the method of Speed (1982) as modified by Antoine Peters (pers. comm.). The antibody detection procedure was as described previously (Ashley et al. 1995). The polyclonal Corl antibody, raised in mouse against the Syrian hamster Corl protein (Dobson et al. 1994) was a gift from Drs. Peter Moens and Barbara Spyropoulos (York University, Toronto, Canada). The production of the Corl antibody and its specificity for the axial/lateral element of the synaptonemal complex has been described previously (Dobson et al. 
1994). Affinity-purified 4779 antibody was detected with goat antirabbit IgG conjugated with fluorescent isothiocynate (FITC) and the mouse anti-Corl with goat antimouse IgG conjugated with Texas Red. Incubation of spermatocytes with 4779 preimmune serum produced only a nonspecific background reaction in all cell types. One hundred twenty-one spermatocyte nuclei were imaged from six males 3 to 12 weeks old for localization studies on Atr and 176 nuclei from four males 3 to 12 weeks old for localization with Atm. In addition 25 oocyte nuclei were imaged from two female fetuses 16 days postconception. Preimmune serum from 4779 and from Atm l produced only a faint generalized nuclear staining pattern on spermatocyte preparations.

\section{Acknowledgments}

We thank Jim Halbrook, Chris Allen, Tony DeMaggio, Teresa Greenstreet, Kelly Hensley, and Kelley Murphy for comments and technical assistance and Rosemary Monaghan for manuscript preparation. We thank Scott Peterson (Los Alamos National Laboratory) for providing purified RPA, Pat Concannon (Virginia Mason Research Center, Seattle) for supplying A-T patient cell lines, and Dave Hill (Oncogene Research Products) for providing ATMl antisera. This work was supported by ICOS Corporation and in part by National Institutes of Health grants GM-49779 to T.A. and CA-60592 to M.S.M. and USDA grant 95-02560 to S.B.M.

The publication costs of this article were defrayed in part by payment of page charges. This article must therefore be hereby marked "advertisement" in accordance with 18 USC section 1734 solely to indicate this fact.

\section{References}

Al-Khodairy, F. and A.M. Carr. 1992. DNA repair mutants defining G2 checkpoint pathways in Schizosaccharomyces pombe. EMBO /. 11: 1343-1350.

Al-Khodairy, F., E. Fotou, K.S. Sheldrick, D.J.F. Griffiths, A.R. Lehman, and A.M. Carr. 1994. Identification and characterization of new elements involved in checkpoints and feedback controls in fission yeast. Mol. Biol. Cell 5: 147-160.

Allen, J.B., Z. Zhou, W. Siede, E.C. Friedberg, and S.J. Elledge. 1994. The SADI/RAD53 protein kinase controls multiple checkpoints and DNA damage-induced transcription in yeast. Genes \& Dev. 8: 2401-2415.

Anderson, C.W. and S.P. Lees-Miller. 1992. The nuclear serine/ threonine protein kinase DNA-PK. Crit. Rev. Eukaryot. Gene Expr. 2: 283-314.

Ashley, T., A.W. Plug, J. Xu, A.J. Solari, G. Reddy, E.I. Golub, and D.C. Ward. 1995. Dynamic changes in Rad51 distribution on chromatin during meiosis in male and female vertebrates. Chromosoma 104: 19-28.

Baker, B.S. and A.T.C. Carpenter. 1972. Genetic analysis of sex chromosomal meiotic mutants in Drosophila melanogaster. Genetics 71: 255-286.

Baker, B.S., J.B. Boyd, A.T.C. Carpenter, M.M. Green, T.D. Nguyen, P. Ripoll, and P.D. Smith. 1976. Genetic controls of meiotic recombination and somatic DNA metabolism in Drosophila melanogaster. Proc. Natl. Acad. Sci. 73: 41404144.

Baker, S.M., A.W. Plug, T.A. Prolla, C.E. Bronner, A.C. Harris, X. Yao, D.-M. Christie, C. Monell, N. Arnheim, A. Bradley, T. Ashley, and R.M. Liskay. 1996. Involvement of mouse MIh1 in DNA mismatch repair and meiotic crossing over. Nature Genet. 13: 336-342.
Banga, S.S., R. Shenkar, and J.B. Boyd. 1986. Hypersensitivity of Drosophila mei-41 mutants to hydroxyurea is associated with reduced mitotic chromosome stability. Mutat. Res. 163: 157-165.

Barlow, C., S. Hirotsune, R. Paylor, M. Liyanage, M. Eckhaus, F. Collins, Y. Shiloh, J.N. Crawley, T. Ried, D. Tagle, and A. Wynshaw-Boris. 1996. Atm-deficient mice: A paradigm of Ataxia-Telangiectasia. Cell 86: 159-171.

Beamish, H. and M.F. Lavin. 1994. Radiosensitivity in ataxiatelangiectasia: Anomalies in radiation-induced cell cycle delay. Int. I. Radiat. Biol. 65: 175-184.

Bellve, A.R., C.F. Millette, Y.M. Bhamagar, and D.A. O'Brian. 1977. Dissociation of the mouse testis and characterization of isolated spermatogenic cells. I. Histochem. Cytochem. 25: 480-494.

Bentley, N.J., D.A. Holtzman, K.S. Keegan, G. Flaggs, A.J. DeMaggio, J.C. Ford, M.F. Hoekstra, and M. Carr. 1996. The Schizosaccharomyces pombe $\operatorname{rad} 3$ checkpoint gene. EMBO $J$. (in press).

Bishop, D.K. 1994. RecA homologs Dmcl and Rad51 interact to form multiple nuclear complexes prior to meiotic chromosome synapsis. Cell 79: 1081-1092.

Blunt, T., N.J. Finnie, G.E. Taccioli, C.G.M. Smith, J. Demengeot, T.M. Gottlieb, R. Mizuta, A.J. Varghese, F.W. Alt, P.A. Jeggo, and S.P. Jackson. 1995. Defective DNA-dependent protein kinase activity is linked to $\mathrm{V}(\mathrm{D}) \mathrm{I}$ recombination and DNA repair defects associated with the murine scid mutation. Cell 80: 813-823.

Boyd, J.B., M.D. Golino, T.D. Nguyen, and M.M. Green. 1976. Isolation and characterization of X-linked mutants of Drosophila melanogaster which are sensitive to mutagens. Genetics 84: 485-506.

Brown, E.J., M.W. Albers, T.B. Shin, K. Ichikawa, C.T. Keith, W.S. Lane, and S.L. Schreiber. 1994. A mammalian protein targeted by G1-arresting rapamycin-receptor complex. $\mathrm{Na}$ ture 369: 756-758.

Brown, E.J., P.A. Beal, C.T. Keith, J. Chen, T.B. Shin, and S.L. Schreiber. 1995. Control of p70 s6 kinase by kinase activity of FRAP in vivo. Nature 377: 441-446.

Cafferkey, R., P.R. Young, M.M. McLaughlin, D.J. Bergsma, Y. Koltin, G.M. Sathe, L. Faucette, W.K. Eng, R.K. Johnson, and G.P. Livi. 1993. Dominant missense mutations in a novel yeast protein related to mammalian phosphatidylinositol 3-kinase and VPS34 abrogate rapamycin cytotoxicity. Mol. Cell. Biol. 13: 6012-6023.

Canman, C.E., A.C. Wolff, C.Y. Chen, A.J. Fornace, and M.B. Kastan. 1994. The p53-dependent G1 cell cycle checkpoint pathway and ataxia-telangiectasia. Cancer Res. 54: 50545058.

Cao, L., E. Alani, and N. Kleckner. 1990. A pathway for generation and processing of double-strand breaks during meiotic recombination in S. cerevisiae. Cell 61: 1089-1101.

Carpenter, A.T.C. 1979. Recombination nodules and synaptonemal complex in recombination-defective females of Drosophila melanogaster. Chromosoma 75: 259-292.

Carpenter, C.L., K.R. Auger, B.C. Duckworth, W.-M. Hou, B. Schaffhausen, and L.C. Cantley. 1993. A tightly associated serine/threonine protein kinase regulates phosphoinositide 3-kinase activity. Mol. Cell. Biol. 13: 1657-1665.

Carr, A.M. 1996. Checkpoints take the next step. Science 271: 314-315.

Carr, A.M. and M.F. Hoekstra. 1995. The cellular responses to DNA damage. Trends Cell Biol. 5: 32-40.

Cimprich, K.A., T.B. Shin, C.T. Keith, and S.L. Schreiber. 1996. cDNA cloning and gene mapping of a candidate human cell cycle checkpoint protein. Proc. Natl. Acad. Sci. 7:2850- 
2855.

Deng, C., P. Zhang, J.W. Harper, S.J. Elledge, and P. Leder. 1995. Mice lacking $\mathrm{p} 21^{\mathrm{CIP1} / \mathrm{WAF} 1}$ undergo normal development, but are defective in Gl checkpoint control. Cell 82: 675684.

Dhand, R., I. Hiles, G. Panayotou, S. Roche, M.J. Fry, I. Gout, N.F. Totty, O. Truong, P. Vicendo, K. Yonezawa, M. Kasuga, S.A. Courtneidge, and M.D. Waterfield. 1994. PI3-kinase is a dual specificity enzyme: Autoregulation by an intrinsic protein-serine kinase activity. EMBO J. 13: 522-533.

Dobson, M.J., R.E. Pearlman, A. Karaiskakis, B. Spyropoulos, and P.B. Moens. 1994. Synaptonemal complex proteins: Occurrence, epitope mapping and chromosome disjunction. $/$. Cell Sci. 107: 2749-2760.

Dvir, A., L.Y. Stein, B.J. Calore, and W.S. Dynan. 1993. Purification and characterization of a template-associated protein kinase that phosphorylates RNA polymerase II. I. Biol. Chem. 268: 10440-10447.

Edelmann, W., P.E. Cohen, M. Kane, K. Lau, B. Morrow, S. Bennett, A. Umar, T. Kunkel, G. Cattoretti, R. Chaganti, I.W. Pollard, R.D. Kolodner, and R. Kucherlapati. 1996. Meiotic pachytene arrest in MLH1-deficient mice. Cell 85: 11251134.

El-Deiry, W.S., T. Tokino, V.E. Velculescu, D.B. Levy, R. Parson, J.M. Trent, D. Lin, W.E. Mercer, K.W. Kinzler, and B. Vogelstein. 1993. WAFl, a potential mediator of p53 tumour suppression. Cell 75: 817-825.

Friedberg, E.C., G.C. Walker, and W. Siede. 1995. DNA repair and mutagenesis. American Society for Microbiology, Washington, DC.

Greenwell, P.W., S.L. Kronmal, S.E. Porter, J. Gassenhuber, B. Obermaier, and T.D. Petes. 1995. TEL1, a gene involved in controlling telomere length in $S$. cerevisiae, is homologous to the human ataxia telangiectasia gene. Cell 82: 823829.

Hari, K.L., A. Santerre, J.J. Sekelsky, K.S. McKim, J.B. Boyd, and R.S. Hawley. 1995. The mei-41 gene of D. melanogaster is a structural and functional homolog of the human ataxia telangiectasia gene. Cell 82: 815-821.

Harper, J.W., G. Adami, N. Wei, K. Keyomarsi, and S.J. Elledge. 1993. The $21 \mathrm{kD} \mathrm{Cdk}$ interacting protein $\mathrm{Cipl}$ is a potent inhibitor of G1 cyclin dependent kinases. Cell 75: 805-816.

Hartley, K.O., D. Gell, G.C. Smith, H. Zhang, N. Divecha, M.A. Connelly, A. Admon, S.P. Lees-Miller, C.W. Anderson, and S.P. Jackson. 1995. DNA-dependent protein kinase catalytic subunit: A relative of phosphatidylinositol 3-kinase and ataxia telangiectasia gene product. Cell 82: 849-856.

Hartwell, L.H. and M.B. Kastan. 1994. Cell cycle control and cancer. Science 266: 1821-1828.

Heitman, J., N.R. Movva, and M.N. Hall. 1991. Targets for cell cycle arrest by the immunosuppressant rapamycin in yeast. Science 253: 905-909.

Helliwell, S.B., P. Wagner, J. Kunz, M. Deuter-Reinhard, R. Henriquez, and M.N. Hall. 1994. TOR1 and TOR2 are structurally and functionally similar but not identical phosphatidylinositol kinase homologs in yeast. Mol. Biol. Cell 5: 105118.

Jackson, S.P. and P.A. Jeggo. 1995. DNA double-strand break repair and $\mathrm{V}(\mathrm{D}) \mathrm{J}$ recombination: Involvement of DNA-PK. Trends Biochem. 20: 412-415.

Jiminez, G., J. Yucel, R. Rowley, and S. Subramani. 1992. The $\mathrm{rad} 3^{+}$gene of Schizosaccharomyces pombe is involved in multiple checkpoint functions and in DNA repair. Proc. Natl. Acad. Sci. 87: 4952-4956.

Kastan, M.B., Q. Zhan, W.S. El-Deiry, F. Carrier, T. Jacks, W.V. Walsh, B.S. Plunkett, B. Vogelstein, and A.J. Fornace, Jr.
1992. A mammalian cell cycle checkpoint pathway utilizing p53 and GADD45 is defective in ataxia-telangiectasia. Cell 71: 587-597.

Kato, R. and H. Ogawa. 1994. An essential gene, ESR1, is required for mitotic cell growth, DNA repair and meiotic recombination in Saccharomyces cerevisiae. Nucleic Acids Res. 22: 3104-3112.

Kleckner, N. 1996. Meiosis: How could it work? Proc. Natl. Acad. Sci. 93: 8167-8174.

Kunz, J., R. Henriquez, U. Schneider, M. Deuter-Reinhard, N.R. Movva, and M.N. Hall. 1993. Target of rapamycin in yeast, TOR2, is an essential phosphatidylinositol kinase homolog required for G1 progression. Cell 73: 585-596.

Lamb, J.R., C. Petit-Frere, B.C. Broughton, A.R. Lehmann, and M.H.L. Green. 1989. Inhibition of DNA replication by ionizing radiation is mediated by a transacting factor. Int. $J$. Radiat. Biol. 56: 125-130.

Lees-Miller, S.P., Y.-R. Chen, and C.W. Anderson. 1990. Human cells contain a DNA-activated protein kinase that phosphorylates simian virus $40 \mathrm{~T}$ antigen, mouse p53, and the human Ku autoantigen. Mol. Cell. Biol. 10: 6472-6481.

Liu, V.F. and D.T. Weaver. 1993. The ionizing radiation-induced replication protein A phosphorylation response differs between ataxia telangiectasia and normal human cells. Mol. Cell. Biol. 13: 7222-7231.

Meyn, M.S. 1995. Ataxia-telangiectasia and cellular responses to DNA damage. Cancer Res. 55: 5991-6001.

Morrow, D.M., D.A. Tagle, Y. Shiloh, F.S. Collins, and P. Hieter. 1995. TEL1, an S. cerevisiae homolog of the human gene mutated in ataxia-telangiectasia, is functionally related to the yeast checkpoint gene MEC1. Cell 82: 831-840.

Nelson, W.G. and M.B. Kastan. 1994. DNA strand breaks: The DNA template alterations that trigger p53-dependent DNA damage response pathways. Mol. Cell. Biol. 14: 1815-1823.

Painter, R.B. and B.R. Young. 1980. Radiosensitivity in ataxiatelangiectasia: A new explanation. Proc. Natl. Acad. Sci. 77: 7315-7317.

Paulovich, A.G. and L.H. Hartwell. 1995. A checkpoint regulates the rate of progression through $\mathrm{S}$ phase in $S$. cerevisiae in response to DNA damage. Cell 82: 841-847.

Petes, T.D., R.E. Malone, and L.S. Symington. 1991. In The molecular biology of the yeast saccharomyces: Genome dynamics, protein synthesis and energetics (ed. J.R. Broach, J.R. Pringle, and E.W. Jones), pp. 407-521. Cold Spring Harbor Laboratory Press, Cold Spring Harbor, NY.

Plug, A.W., J. Xu, G. Reedy, E.I. Golub, and T. Ashley. 1996. Presynaptic association of Rad51 protein with selected sites in meiotic chromatin. Proc. Natl. Acad. Sci. 93: 5920-5924.

Roeder, G.S. 1990. Chromosome synapsis and genetic recombination. Trends Genet. 6: 385-389.

Romrell, L.J., A.R. Bellve, and D.W. Fawcett. 1976. Separation of mouse spermatogenic cells by sedimentation velocity. A morphological characterization. Dev. Biol. 49: 119-131.

Rowley, R., S. Subramani, and P.G. Young. 1992. Checkpoint controls in Schizosaccharomyces pombe, $\operatorname{radl}$. EMBO /. 11: 1335-1342.

Sabatini, D.M., H. Erdjument-Bromage, M. Lui, P. Tempst, and S.H. Snyder. 1994. RAFT1: A mammalian protein that binds to FKBP12 in a rapamycin-dependent fashion and is homologous to yeast TORs. Cell 78: 35-43.

Sanchez, Y., B.A. Desany, W.J. Jones, W. Liu, B. Wang, and S.J. Elledge. 1996. Regulation of RAD53 by the Atm-like kinases $\mathrm{MECl}$ and TELl in yeast cell cycle checkpoint pathways. Science 271: 357-360.

Savitsky, K., A. Bar-Shira, S. Gilad, G. Rotman, Y. Ziv, L. Vanagaite, D.A. Tagle, S. Smith, T. Uziel, S. Sfez, M. Ashkenazi, 
I. Pecker, M. Frydman, R. Harnik, S.R. Patanjali, A. Simmons, G.A. Clines, A. Sartiel, R.A. Gatti, L. Chessa, O. Sanal, M.F. Lavin, N.G.J. Jaspers, A.M.R. Taylor, C.F. Arlett, T. Miki, S.M. Weissman, M. Lovett, F.S. Collins, and Y. Shiloh. 1995. A single ataxia telangiectasia gene with a product similar to PI-3 kinase. Science 268: 1749-1753.

Seaton, B.L., J. Yucel, P. Sunnerhagen, and S. Subramani. 1992. Isolation and characterization of the Schizosaccharomyces pombe rad3 gene, involved in the DNA damage and DNA synthesis checkpoints. Gene 119: 83-89.

Sedgwick, P.P. and E. Boder. 1991. Ataxia-Telangiectasia. In $\mathrm{He}$ reditary neuropathies and spinocerebellar atrophies (ed. J.M.B.V. deJong), pp. 347-423. Elsevier Science Publishing Company, New York, NY.

Shiloh, Y. 1995. Ataxia-telangiectasia: Closer to unraveling the mystery. Eur. J. Hum. Genet. 3: 116-138.

Speed, R.M. 1982. Meiosis in foetal ovary I: An analysis at the light microscopy level using surface spreading. Chromosoma 85: 427-437.

Stack, J.H. and S.D. Emr. 1994. Vps34p required for yeast vacuolar protein sorting is a multiple specificity kinase that exhibits both protein kinase and phosphatidylinositol-specific PI 3-kinase activities. I. Biol. Chem. 269: 31552-31562.

Stern, H., and Y. Hotta. 1984. Chromosome organization in the regulation of meiotic prophase. In Controlling events of meiosis (ed. C.W. Evans and H.G. Dickenson), pp. 161-174. Society for Experimental Biology, London, UK.

Sun, H., D. Treco, N.P. Schultes, and J.W. Szostack. 1989. Double-strand breaks at an initiation site for meiotic gene conversion. Nature 338: 87-90.

Terasawa, M.A., A. Shinohara, Y. Hotta, H. Ogawa, and T. Ogawa. 1995. Localization of RecA-like recombination proteins on chromosomes of lily at various meiotic stages. Genes \& Dev. 9: 925-934.

Walworth, N., S. Davey, and D. Beach. 1993. Fission yeast chk1 protein kinase links the rad checkpoint pathway to $c d c 2$. Nature 363: 368-371.

Walworth, N.C. and R. Bernards. 1996. rad-dependent response of the chk1-encoded protein kinase at the DNA damage checkpoint. Science 271: 353-356.

Weber, L. and B. Byers, 1992. A RAD9-dependent checkpoint blocks meiosis of cdc13 yeast cells. Genetics 131: 55-63.

Weinert, T.A., G.L. Kiser, and L.H. Hartwell. 1994. Mitotic checkpoint genes in budding yeast and the dependence of mitosis on DNA replication and repair. Genes \& Dev. 8: 652-665.

Wiler, R., R. Leber, B.B. Moore, L.F. VanDyk, L.E. Perryman, and K. Meek. 1995. Equine severe combined immunodeficiency: A defect in V(D)I recombination and DNA-dependent protein kinase activity. Proc. Natl. Acad. Sci. 92: 11485-1 1489.

Wright, J., S. Teraoka, S. Onegut, A. Tolun, R.A. Gatti, H.D. Ochs, and P. Concannon. 1996. A high frequency of distinct ATM gene mutations in Ataxia-Telangiectasia. Am. J. Hum. Genet. (in press).

Xu, Y., T. Ashley, E.E. Brainerd, R.T. Bronson, M.S. Meyn, and D. Baltimore. 1996. Targeted disruption of ATM leads to growth retardation, chromosomal fragmentation during meiosis, immune defects, and thymic lymphoma. Genes \& Dev. (this issue). 


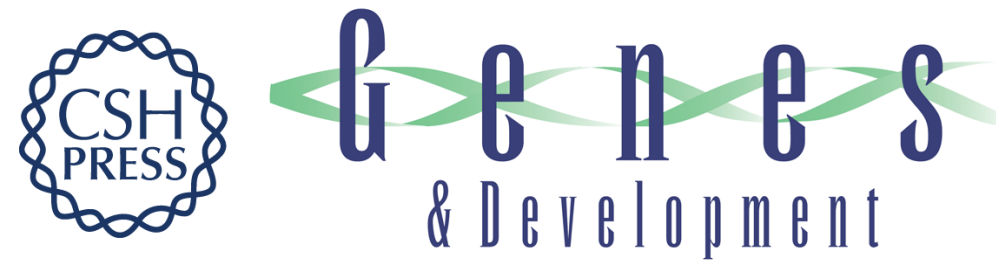

\section{The Atr and Atm protein kinases associate with different sites along meiotically pairing chromosomes.}

K S Keegan, D A Holtzman, A W Plug, et al.

Genes Dev. 1996, 10:

Access the most recent version at doi:10.1101/gad.10.19.2423

References This article cites 70 articles, 28 of which can be accessed free at:

http://genesdev.cshlp.org/content/10/19/2423.full.html\#ref-list-1

License

Email Alerting

Service

Receive free email alerts when new articles cite this article - sign up in the box at the top right corner of the article or click here.

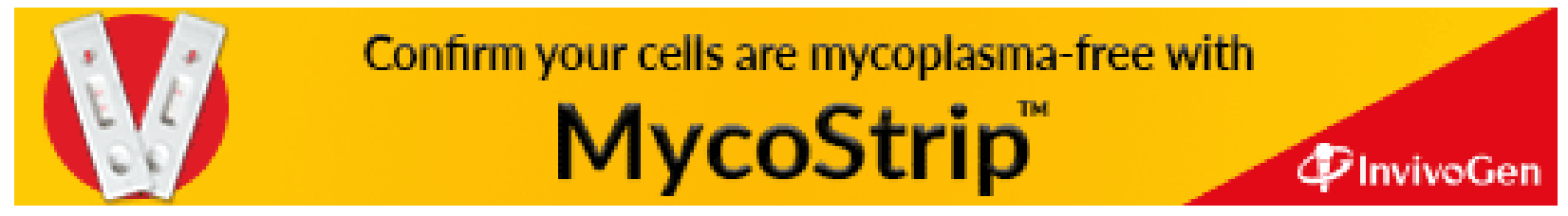

